\begin{tabular}{c} 
Volume and Issues Obtainable at Center for Sustainability Research and Consultancy \\
Responsible Education, Learning and Teaching in Emerging Economies \\
ISSN: 2708-4310 (E): 2708-4183 \\
Volume 2: No.1, June 2020 \\
$\begin{array}{c}\text { CSRC } \\
\text { Jofit }\end{array}$ \\
Journal homepage: $\underline{\text { www.publishing.globalcsrc.org/relate }}$ \\
\hline
\end{tabular}

\title{
Strengthening Research-Education-Extension (R-E-E) Linkage in New Context of Federal Structured Nepal
}

\section{${ }^{1}$ Mahesh Jaishi, ${ }^{2}$ Purna Bahadur Nepali, ${ }^{3}$ Sandhya Rijal, ${ }^{4}$ Benju Dhakal}

${ }^{1}$ Assistant Professor, Institute of Agriculture and Animal Science (IAAS), Nepal, mahesh.jaishi@gmail.com

${ }^{2}$ Fullbright Fellow and Adjunct Faculty at Kathmandu University, Nepal, kumar2034@gmail.com

${ }^{3}$ MS scholar, Agriculture and Forestry University, Rampur Chitwan, Nepal, sany.riz@gmail.com

${ }^{4}$ MS Scholar, Post Graduate Program, Institute of Agriculture and Animal Science (IAAS), Tribhuvan University, Nepal, skgbenjana@gmail.com

\begin{tabular}{l} 
ARTICLE DETAILS \\
\hline History \\
Revised format: May 2020 \\
Available Online: June 2020 \\
Keywords \\
CAESC, Land-grant institution, $R$ - \\
E-E linkage
\end{tabular}

JEL Classification:

I20, I23

\section{ABSTRACT}

Objective: The objective of this paper is to examine major limitations in past efforts in Nepal to create linkage between agricultural research, extension and education and suggest appropriate measure to overcome these limitations in context of federal structure in Nepal.

Methodology: This paper is a review of government policy papers, articles, books, reports and websites. Primary data has been created by key informant interview among policymakers, faculties and researchers from three major stakeholders of agricultural research, extension and education.

Result: The present linkage between research extension and education (REE) are weakest in terms of service delivery, which is aided by inadequate policy, shared programs, and functional linkage between institutions providing REE services in Nepal. Three way partnership in land-grant model in every state can help agricultural extension to meet the goal of rural community development; the partnership being in between state government through ministry departments, and local government through municipalities and Community Agriculture Extension Service Centers (CAESC).

Implication: A typological model is presented suggesting organizational and operational linkage strategies to avoid scattered efforts and services through collaboration of community initiatives by restructuring and revitalizing existing institutional structures.

\section{(C) 2020 The authors, under a Creative Commons Attribution-} NonCommercial 4.0

Corresponding author's email address: mahesh.jaishi@ gmail.com

Recommended citation: Jaishi, M., Nepali, P.B., Rijal, S., \& Dhakal, B. (2020). Strengthening Research-EducationExtension (R-E-E) Linkage in New Context of Federal Structured Nepal. Responsible Education, Learning and Teaching in Emerging Economies, 2(1), 1 -11

\section{Introduction}

Agricultural Extension and Advisory Services (EAS), significantly aides in improving the agriculture system. For many years, providing agriculture extension services has been ensured by different states throughout the world (Sadhigi, 2005). Learning priorities of different tiers of government vary and continuously evolve over time. Extension is obligated to direct the resource use addressing the changing context of government. The ever expanding 
needs of citizen should be well addressed for an efficient i.e. relevant, research based and high-quality extension education (Bull et al, 2004). Technological advancement has raised a need to reform the public sector service provision. The agriculture sector is demanding increased market based productivity and vigor to face the competition. Policymakers are therefore emphasizing corresponding policy reforms that serve to meet the demand of changing socio-economic context, and are interested in exemplary cases that serve to develop a vision in transitional, less industrialized countries (Hoffmann et al., 2000).

The paradigm shift in agricultural research and technological advancementdictates the need to transform prevalent structure, management and function of agricultural research and extension system to more dynamic and adaptive towards the changing environment (Anandajayasekaram et al., 2008; Paudel, gill and Rajotee, 2013).Optimizing the performance of existing extension models (Conventional, T\&V, IRDP, FtF, group approach PPP) for improving REE linkage is needed in Nepal.Improvement in research backstopping, converging resource use and service delivery in supplementary and complementary modes (Sadamate, 2018),enhanced penetration among small and marginal farmers in wider sectors and area coverage, are required to reduce systematic "bottlenecks"(Van Crowder \& J. Anderson, 1997) and facilitate strong REE linkage;improving overall performance, and contribution to development by national agricultural technology system.

This paper provides measures for improvements in government's strategy and policy to cope with major drawbacks in the past and current efforts for REE linkage in agriculture of Nepal. This paper examines REE linkage problems, changing REE orientation in Nepal, issues in world's experience on land grand institution and integrated agricultural REE. This paper elaborates the innovation in REE linkage adaptable to community intiatives envisioned in the Agriculture Development Strategy of Nepal (2015-2055) that might minimize "linkages Problem". Therefore, this review will help us to identify and better understand the issues that need to be addressed with agriculture REE in the country.

\section{Literature Review}

\subsection{REE Linkage: Activating Existing Forums and Follow Up}

Sadamate (2018) argues the need of extending research backstopping, scientist interface with the farmers and augmented technological support for extension field functionaries. Rewarding and mainstreaming farmer's led innovation is required for enhancing technology use by micro-level farmers. REE linkage mechanisms vary according to different levels in Nepal. The Transfer of technology (ToT) model, farming system research model and the innovation system model are the linear top-down models identified (Teklewold and Gulti, 2016) that link agricultural extension and research in Nepal. Application of these models by extension, have linked the actors in value chain of the agricultural commodities in the past. There are four varied agriculture REE linkage mechanisms in Nepal.

National: NARC, tripartite meeting, technical panel meeting, ATWG, seasonal crop workshop

Regional: Research station, commodity research program, outreach research program, RATWG

District: DADO, currently concept of Agriculture Knowledge Center, DAPDIC

Community: Farmers group, cooperatives, village-level planning \& review workshop (VLPRW)

Improving the REE linkage agenda through proactive participation and responding farmer's needs through dynamic research and development forums is necessary. Creating new arrangements in the context of new structure in the state and municipality level is necessary to bridge the REE linkage fap in the new federal structure of Nepal. Substantial increase in extension research input is essential to strengthen the crucial but overlooked foundation of knowledge of extension discipline (Sadamate, 2018). In India National Institute of Agriculture Extension Management (MANGE), State Agriculturral Management and Extension Training Institutes (SAMETIS), Agriculture Technology Application Research Institute (ATARIS) and Directorate of Extension (DOE) have somewhat formed research-extension window. Inadequacy of such research-extension window in Nepal can be fulfilled through deliberation of broader extension research areas from the central government. Need based specificity of such research areas should be done annually in local level. For instance selectively specified master and doctorate dissertation can be considered for academic and application purposes, and DOE of IAAS and AFU may initiate this process. 
The privatization of three core institutions of agriculture knowledge triangle (research, extension and higher education) in restructured context has increased competition with their public counterparts (Anandajayasekaram et al., 2008). Countries across the world have varying administrative levels (central, regional, and local) responsible for linkage between agricultural research, extension and education. The target of agricultural research and extension system is to enhance the agricultural output of farmers through easier availability of farming innovations. Thus actions of agricultural researchers and extension workers should focus on strengthening research-extension linkage, which ultimately affects the agricultural output of farming families (Sadhigi, 2005). Recently the link-chain mechanism of agricultural research and extension in developing countries has been targeting the needs and priorities of the farmers. Being the target hub, farmers are articulating their problems and needs, which is creating a two-way communication in the function of agricultural extension and research linkage. Actions of agricultural research and extension are revolving around farmers as their primary stakeholder and influencing the dissemination of agricultural technology (Belay, 2008).

Public research agencies are dominant over University and private organizations involved in agricultural research in developing economies (Gauchan and Paudel, 2012). Developing countries with federal systems have a central public research body responsible for management, funding, coordination, and implementation of research activities, which overshadows the function of the regional level and local level agencies working for adaptive research (ICAR, 2010).

The increasing demand for resources in agricultural research increases the complexity of the interdependent relationship among the different levels of governments regarding the conduction and implementation of the research (Bellamy and Brown, 2010). The stable extension services provided by the public sector have become stagnant, and the national agricultural extension system is suffering from inadequate technology transfer among farmers and agribusiness operators. There are no formal linkages between research (NARC research farms) and extension (extension agents) and pre-service educational institutions like IAAS, CTEVT, HICAST in the field (Subedi and McNamara, 2011).

There are either top-down or bottom-up type of research-extension linkage in a country depending upon relative status of agricultural research and extension organizations and the procedure of research i.e. finding research problems, themes and results (Agbamu, 2000). Depending upon socio-cultural variances and adoption of different development models, seven different types of research-extension linkage mechanism exist in the world namely apex management, matrix management, coordinating committees/meetings, communication units or liaison departments, use of task force, staff exchanges and co-operation between universities' research programs and extension organizations (Agbamu, 2000). In Nepal all of the linkage mechanisms are found, however none of them is well functioned.

\subsection{Linkage of Agriculture Research and Extension in the World}

Southeast Asian Nations primarily face the strategic research management issues in national systems while building up appropriate research-extension linkage mechanism, resulting in an effective relationship between "developer", "deliverer" and "consumer" of a useful technology, encompassing all three functions of REE (Samanta and Sontai, 2006) which is necessary to attain the objective of increased agricultural production (Rolling 1990). Multiple agricultural research institutes and different forms of councils were established in different Asian countries during 1960s and 70s. International research centers like IRRI and CIMMYT were linked with aim to organize the structure, consolidate and coordinate the growth and transformation of agricultural research and extension system. In Asian countries, the improvement of accountability, decentralization, partnership based privatization, demand-driven, and cost-friendly research and extension process has been prioritized in public sector after the Green Revolution in late 90s. Different examples of regional collaboration were cited from various countries that include International Agricultural Research Centers (IARCs), NGOs and the private sector.

Inefficient coordination among research, extension and education has been indicated (Paudel, Bhattarai and Subedi, 2016), however, collaboration and work division between research and agricultural university is not clearly outlined and it is not clear as to what the decentralization of the research means If these signify experimenting in field research, its subjects and questions are not precise. There is no clarity as to which is the responsible agency to conduct the 
research, how to check the agricultural labor loss. Establishing the Community Agricultural Extension Service Centers (CAESCs) seems rather practical in terms of the proposition. However, there is a fear for these programs as well, similar to other proposed programs, of not being implemented and limited on the papers as means of their execution is not clear (Paudel, Bhattarai and Subedi, 2016). This document proposes the privatization of extension. The present subsistence farmers in rural areas are not in a position to afford private extension services. It is not apparent how the present extension service under the Ministry of Agricultural Development will exist and what will it do if expansion is indeed privatized. In the developing world model, farmers produce agricultural technology, transfer the knowledge, and materials through horizontal and vertical ways with the help of extension agents, research institutions and private sectors (Taylor and Bhasme, 2018).

\subsection{Federal Restructuring and Agriculture Research and Extension System in Nepal}

Nepal has transitioned from unitary to federal democratic republic government. With this historic transition, the problem of governing uneven distribution of population in terms of socio-economic and topographical aspects has also aroused. The new Nepali constitution envisages the lower tiers of government as meaningful contributors and drivers of planning process (Jaishi, Nepali and Shahi, 2018) and elected representatives in the government of seven provinces are highly expected to fulfill their mandates. Kyle and Resnik (2016) noted that "this institutional transition offers a unique opportunity to address existing weaknesses in the current policy process and institutional structure, including the agricultural sector."

With the change in structure, the role and authority of agriculture extension, previously devolved and delegated from the central government, has now constitutionally mandated to the local government (Subedi et al., 2018). The agriculture research function is still in the domain of central government, whereas the technical backstopping and resource management function is still in the domain of central government, whereas the technical backstopping and resource management function is with the state government. Recently GoN proposed the mostly awaited new proposal called KrishiGyan Kendra (KGK) which is not yet fully operational. Thapa (2018) proposed the Agriculture Knowledge Center (AKC) as fully equipped with lab facilities, in house specialist with the post graduate specialist. He also urged to include the extension position in the field of home science, post-harvest, and agri-business having sufficient capabilities of conducting problem-solving research trails in the farmer's field.

Local-level entity requires a clearly defined and robust functional linkage mechanism to make them more accessible to farmers as envisaged in ADS. However, there are role clarity problems between and within research and extension institutions (Paudel, Bhattarai, and Subedi, 2016). Now, the country has been transformed into federal governance systems that need major REE entities and flagship programs at the federal level, seven at the provincial level, and 753 entities at the local level (Jaishi, Nepali and Shahi, 2018). In a federal structure, the presence of a formal local level entity is dense. Hence, people are at closer proximity to local level entities, which is expected to improve the execution and implementation of ADS. Pre-requisite for REE linkage is to evolve and institutionalize effective execution and implementation entities and mechanisms. However, the agriculture academic institution could not be as dense as local entities. So the linkage of REE entities demands a clearly defined and reliable functional mandate. There are likely chances that farmer's access to technology and extension advisory services will worsen further in the federal structure. Now, the government is planning to make research an autonomous entity (Gauchan and Paudel, 2012). Hence the structure and governance system of both research and extension is still in the process of finalization.

\subsection{The Role of Agriculture Universities in Modern Society}

The traditional function of teaching and research are beign enhanced with training for specialization, personality development and practical application of the theories for problem-solving in Universities (Dangol, 2004). SAUs in India (similar concept as Land-grand universities of the United States) are state funded autonomous organizations responsible for agricultural research, extension and education. Their establishment, is a crucial landmark in strengthening agricultural extension education system in India (Meena and Swanon, 2013). As the context of universities varies across a country, an extension education is likely to evolve at a local level accordingly, being responsive to the needs of the agricultural community. This kind of adaptation at the local level drives the future of extension education at national level. For example, integration of adaptive research in universities who formerly 
emphasized basic research, coordinating and facilitating agricultural community activities, paid or unpaid technical advice and services in farmer's issues, etc. may help universities specialize based on market demand. There will be differences among the universities, however, attributes like a result-driven, science-based, efficient use of public funds and suitable delivery mechanism relevant to customers and producers should distinguish the national extension system in the future. The result of this transition will be seen in all universities across the world, as the access of people to universities will increase from few to many. However, universities in developing countries face additional responsibilities could be summarized in following of the three points.

1. The most distinctive feature of the modern agricultural university around the world is its integrated program of teaching, research and extension.

2. In addition to the traditional function like teaching and research, the extension which is emerged as the provision of educational service and program to the people, and remained outside the boundary of the campus, is now generally accepted as one of the main functions of an agricultural college or university.

3. A comprehensive example of this system is found in the land grant institution of the US, which was established after the Morill Act 1862, providing at least one university-level institution in each state. The trilogy role of teaching, research and extension are the characteristics of these land grand institutions of the United Nations, which are considered the world's most extensive educational program beyond the boundaries of their campus in the form of field extension activities for farmers, homemakers and youth.

Private and public universities other than land-grant universities also offer outreach programs to enhance the socioeconomic status of the rural population (Schitjer, 1991). Many states of the US have established Rural Development Centers (RDC) who work for extension outreach independent of the land grant universities. The extension has a comparative advantage in aiding rural development by creating alink between technical assistance provided by land grant universities, research and community services through local government officers (Schitjer, 1991). In countries like Nigeria, according to the need of local government, the national agricultural research system has been developed into specialized universities and faculties of agricultural crops and veterinary, research institutes and experimental stations for generating agricultural innovation aiming rural development (Adesiji, Ibrahim and Komolafe, 2017).

\section{Methodology}

This paper is a review document of textbook, journals, status paper, working paper and policy paper regarding issues of state restructuring and decentralized agricultural extension in federalized context of Nepal. Desk study was done to generate, examine, analyze and interpret the data (Onyekachi, 2016) of policies and documents, to elaborate the implication of provision for land and agriculture by the Constitution of Nepal 2015. This paper also includes the result of observation of EAS activities, author's experiences, and three major stakeholder's opinions as primary data.

\section{Discussion}

\subsection{Agriculture Research, Education and Extension Service in Nepal}

In Nepal, agricultural extensions system provided under Department of Agriculture in MoAD, Department of Livestock series in MoLD, education provided by CTEVT, Agriculture information and training center (AITC), Agriculture and Forest University and Tribhuvan University are recognized under pluralistic extension system by Nepal agriculture policy (2004). Recently, 55 new structures in the name of KrishiGyan Kendra (KGK), in the place of former DADO and DLSO (378 Agriculture and 900 livestock service centers throughout the country) have been established to provide agriculture and livestock related services. Besides this, private organizations and agro-vet service providers are working for providing extension service to the farmers (Suvedi and Mc Namara, 2012).

Formerly, agricultural extension services were carried on district level, after LSGA was mandated in Nepal. The grassroot level functionaries of extension being 22,000 farmer's groups and more than 1500 dairy cooperatives as consumers, who got services in Illaka level from agriculture sub-service centers (ASSC) in VDCs, and agriculture service centers (ASCs). They were monitored from District Agriculture Development Office (DADO) and District Livestock Service Office (DLSO) in each of 75 districts (Suvedi and McNamara, 2012).

Nepal Agricultural Research Council (NARC), is an autonomous government body that conducts 400 research projects annually, mainly focusing on technology generation (Joshi, 2016).Agricultural Research Council Act (1991) 
regulates NARC, and it conducts research to develop skills and technologies for increasing national productivity and ensures the goal of food security (Gauchan and Paudel, 2012). NARC conducts research on sectors like agronomy, horticulture, livestock and fishery through network of regional research stations and farms that serve as an outreach branch.There are a total of 56 offices and 50 outreach sites of NARC covering different agro-ecologies, organized in former structure of regional agricultural research stations (RARS) in four development regions, two national research institutes (NARI, NASRI), 13 agricultural research stations (ARS), 14 commodity programs and 22 central divisions. This was aimed for research exposure with farmers and their validation (Paudyal, 2011). For research to be more meaningful, it must be linked with extension, and vice versa (Mishra et al., 2018). However, contrary to the expectation there is a lack of coordination between scientist and extension worker as a major issue concerning building an effective mechanism for deliberate knowledge interface between scientists and farmers (Joshi, 2016).

Constitution of Nepal (2015) has defined Nepal as a federal nation with three tier system of government that delineates the legislation power into central, province and local levels. There are 753 local levels (6740 wards, 460 rural municipalities, 276 municipalities, 11 sub-metropolitan cities and 6 metropolitan cities) in Nepal that help for proper governance of development programs (Jaishi, Nepali and Shahi, 2018).

The Agriculture Development Strategy of Nepal (ADS-2015- 2035) emphasizes decentralization of extension system through establishment of Community Agricultural Extension Service Centers(CAESC) in each VDCs, capacity building and backstopping the services of CAESC andvoucher system for access to the best service by consumers which will help to enhance REE coordination taking agro-enterpreneur's needs and priorities into consideration(MoAD, 2014).

The history of agricultural education in Nepal dates back t o1937, when the first vocational agriculture school was started in the country (Joshi, 2016). However, the formal system of agricultural education begins only after the establishment of the school of agriculture in 1957 in Kathmandu as part of the department of agriculture. With the start of the $20^{\text {th }}$ centuryseveral private and government colleges were established to meet the growing demand form agriculture technicians (Paudel, Gill and Rajotee, 2013). Currently, in Nepal, there are altogether ten universities and four universities (AFU, Far-western, Purbanchal, TU) providing agriculture education through academic programs of the 12 colleges that are operating over the country and around 10000 students are enrolling per year. Despite its stagnant growth for half a decade after establishment, Institute of agriculture and animal Sciences has provided comprehensive education and produced highly competitive human resources as compared to agriculture graduates internationally. At present, more than 12 private and affiliated agricultural colleges and polytechnic institute in Nepal are aiding for higher education in agriculture.

National agriculture research extension and education system of Nepal comprises of numerous fragmented sectors and underdeveloped innovation system that segregate research and extension activities into different processes and attempt to link these activities on the basis of periodic assemblies. The ad-hoc committees result in insufficient capacity for creating and adapting to innovation at the national and regional levels. Such integrated committees view farmers as passive recipients of technology.

\begin{tabular}{|l|l|l|l|l|l|}
\hline \multicolumn{2}{|l|}{ Table 1: Research education and extension (REE) institution and their major functions in Nepal } \\
\hline REE Institution & $\begin{array}{l}\text { Academic } \\
\text { program }\end{array}$ & $\begin{array}{l}\text { On-farm } \\
\text { research }\end{array}$ & $\begin{array}{l}\text { Training of } \\
\text { farmers }\end{array}$ & Dissemination materials & $\begin{array}{l}\text { Advisory } \\
\text { service }\end{array}$ \\
\hline NARC (Research) & & $\mathrm{X}^{\mathrm{R}}$ & & $\mathrm{X}^{\mathrm{R}}$ & $\mathrm{X}^{\mathrm{R}}$ \\
\hline AAI (Education) & $\mathrm{X}^{\mathrm{R}}$ & $\mathrm{X}^{\mathrm{R}}$ & $\mathrm{X}^{\mathrm{P}}$ & $\mathrm{X}^{\mathrm{p}}$ & $\mathrm{X}^{\mathrm{p}}$ \\
\hline AKC (Extension) & & & $\mathrm{X}^{\mathrm{R}}$ & $\mathrm{X}^{\mathrm{R}}$ & $\mathrm{X}^{\mathrm{R}}$ \\
\hline ABPTC (Training) & & & $\mathrm{X}^{\mathrm{R}}$ & $\mathrm{X}^{\mathrm{R}}$ & $\mathrm{X}^{\mathrm{R}}$ \\
\hline CTEVT (Skill) & $\mathrm{X}^{\mathrm{R}}$ & & $\mathrm{X}^{\mathrm{p}}$ & & \\
\hline
\end{tabular}

Adapted and modified from Belay 2008.

$\mathrm{X}$ : activities carried out on regular basis.

$\mathrm{X}^{\mathrm{o}}$ : activities carried out occasionally.

$\mathrm{X}^{\mathrm{p}}$ : activities as part of externally funded projects. 
Table 1 indicates that all seven institutes reported have provided technical assistance, advisory services and information materials like leaflets and manuals related to extension. However, the service was occasional, area covered was limited to close vicinity, and use of farmer-friendly languages was sparse. Only three of the seven had conducted on-farm research activities and agriculture academic institutions (AAI) provided wider range of extension services to the farmers, but the services are irregular due to multiple reasons.

After successful integration of agricultural research, teaching and extension by land-grant universities in the United States, USAID supported establishment of institutions working in similar modality in different countries of Africa, Asia and Latin America (Sadhighi, 2005). However due to insufficient policy coverage, inadequate budget and excessive staff turnovers, such academic institutions could not bring desired changes (FAO, 1991) in countries like Ethiopia, Malawi, Morocco, Nigeria, India, Indonesia, Thailand, Brazil and the Dominican republic Mexico (Wilson, 1993).

Despite active engagement of AAI, its performance in agricultural research is dismal. Thus it is imperative to strengthen AAI to improve their efficiency in meeting national agriculture research agenda through common platform between relevant actors. A new paradigm of agricultural research and extension is necessary where famers should decide and undertake required experiments facilitated by researchers, academicians and extension workers.

\subsection{Community Agriculture Extension Service Center (CAESC): Integrating REE with Community}

How relevant is the land-grant philosophy and mission today? This question is frequently raised given the ubiquitous goal of "teaching, research and public service" now claimed by virtually every public university (Frye, 1993). Moreover, there is growing enthusiasm within higher education in incorporating experimental "community based learning" into the undergraduate curriculum for the research that draws upon a sense of civic responsibility and inculcates a commitment to community service and practical implication of university knowledge in solving community problems (Stoecker, 2014).

Local governments should emphasize in creating inclusive agrarian transformations through enhanced REE linkage. Relevant changes in policy documents, re-organization of existing institutions, establishment and capacity building of specialized universities, based on political commitment agenda, constitutional provision, and demand of farmers needs to be prioritized for development (Agbamu, 2000). The political decision made by former president of the United States Lincoln, for instance can be taken as an example of such desirable political decision (Jaishi, Nepali and Shahi, 2018).

Learning experiential exposure (LEE), animal health camp, plant clinic, IPM schools in farmer's field, establishment of Agriculture Science Center (ASC) in Palung, along with pipeline project of adding more ASCs in Gorkha, Kalikot and Dhading, seed processing plants for quality seeds provision to farmers are some efforts made by AFU to link the research, extension and education with the community (www.afu.edu.np). Establishment of Research Development Training and Extension Center (RD-TEC) in Lamjung campus as a research and extension wing of campus and Radio room in Paklihawa Campus as a broadcasting center by IAAS are some activities to coordinate research, extension and development activities done so far by agriculture education institutions of Nepal (www.iaas.edu.np). Further, Directorate of research and Publication (DoR) of IAAS coordinating and conducting research, publication, field extension activities through bilateral project and program.

Many of those who used this analogy recognized that the circumstances confronting agriculture academic institutions (AAI) in Nepal under universities and institutions are radically different from those of land grant universities. But the land-grant universities remained the one much-revered example of how substantial federal support for higher education had addressed the needs of American people when it was predominantly rural. Given this historical memory on the part of policymakers and university leaders, it seemed only natural that this great achievement is extended to state universities in the nation. Land grant system model of the United States seems to be most fruitful model that can be referred during design of new REE linkage mechanism by Nepal for sustainable improvement in the agriculture sector during the implication of federalization concept. 
Efficient linkage system of research, education and extension mechanism throgyh community platform to incorporate needs and problems of agro-producers, entrepreuners, processors marketers is will be the best mechanism to link all concerned stakeholders. Inadequacy or absence of such REE platforms in Nepal can be coped with building appropriate CAESC plateform. Building a successful platform demands change in thinking and working modality to fully utilize the benefits of the model under use. CAESC model susgested in ADS (2015-2035) aims to solve local problems and to build capacity among people to solve their own problems in community base engaging multistakeholders in the common palce. Transforming the process of knowledge transfer into community based research and extension approach requires long term collaboration of AAI. research institutes and local government. A meaningful community development project in CAESC model requires gathering external resources, involving multiple expertise including community members and multiple disciplines via learning exposures or practicum assessments provision of an academic institute. Constituinal and legal provisions guaranted by the the Nepal Constitution (2015) and Local Government Operation Act (2017)are the fundamental policy, that provide a base to stand these community platemform.

The adjacent figure explains CAESC board (ADS, 2014) as primary link maker, and central anchor in the community level which acts as a bridge to directly engage different AAIs, research bodies like NARC and higher education institutions into testing and shaping tripartite functions of REE through program designs that help to expand area and capacity of ground level extension activities. CAESC board ensures sustainable collaboration of AAI, research institution, private agencies to obtain information support and capacity building trainings, and utilizes the resources provided by higher education institutions to empower communities to develop, design and lead community

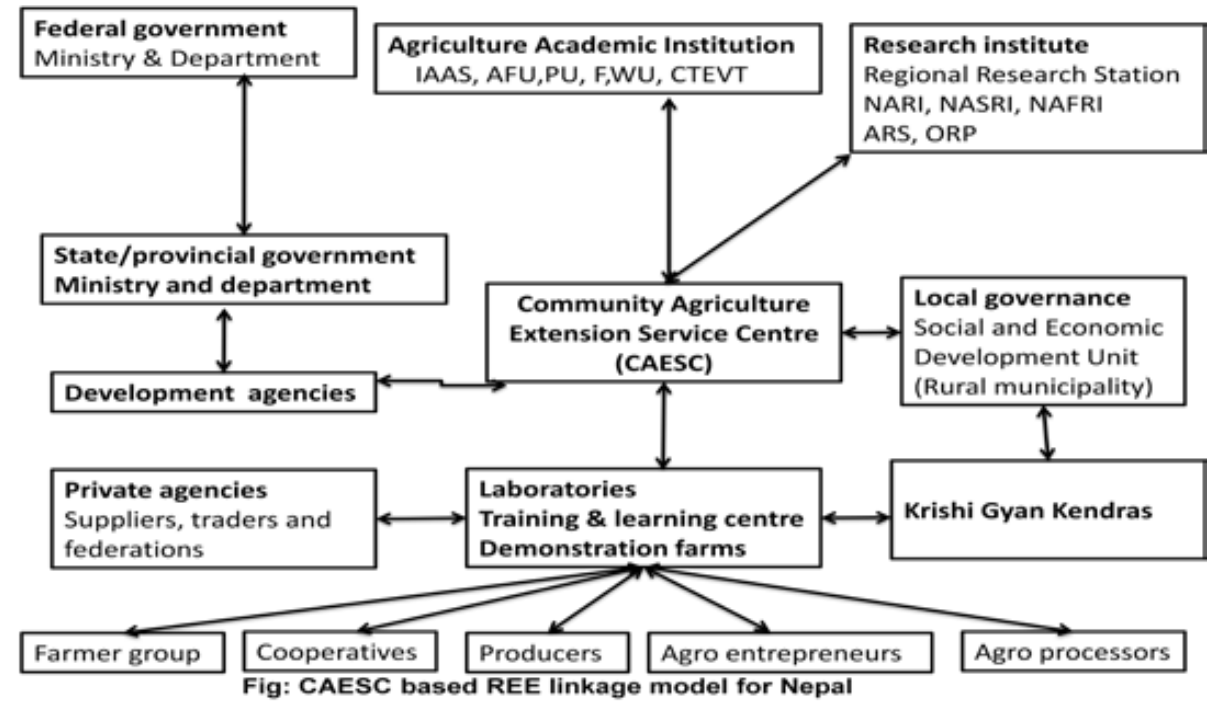
development projects producing meaningful outcomes. Higher education bodies will facilitate coordinate with CAESC in research and capacity buidling in particular. Like any new model, it requires a robust enabling environment in terms of legal ,fiscal, policy, strategy, infrastructure, economical and most importantly thinking and adopting system.

\section{Conclusion and Way Forward}

The access and quality of advisory services as a product of REE can be improved through greater participation of the community in managing, financing, and controlling the REE platform and the state and rural and urban municipalities still has an important, though changing, roles, responsibilities and functions in the new federal context. Many of the principles emerging from the federalization context are applicable in transitional and less industrialized countries like Nepal; however, appropriate strategies need to be locally defined. Based on several ideas foregoing discussion, the following status of REE recommendations for enhancing the REE linkage are worthy of consideration and further exploration:

1. The actors of present national agriculture research extension and education of Nepal understand research and extension as separate processes and try to link these activities on basis of periodic assemblies. The ad-hoc committees result in insufficient capacity for creating and adapting to innovation at the national and regional levels. Such integrated committees view farmers as passive recipient of technology.

2. Access of farmers to the output should be increased and iteration of organizations governing research, extension and education should be considered as interlinked and overlapping process rather than competition among themselves by the respective organizations. 
3. The ideal form of linkage among REE is through fragmented REE system characterized by top-down planning, and bringing together high-level decision- makers through strategic innovation platforms. This eases scaling up of proved technologies throughout the nation.

4. Upgrading curriculum by placing less emphasis on theoretical models and more on practical applications of research that is relevant tot farmer's needs would ensure that REE stakeholders receive the necessary skill sets to be successful.

5. It is imperative to strengthen the research activities of AAI to improve their contribution in national agriculture research agenda, and by extension, goal of agricultural development.

6. Strategic research and extension planning - defining need based research priorities, proper budget and time allocation, and incentivizing multi-disciplinary research, should be given emphasis.

7. Proper delegation of roles and responsibilities of AAI in research and extension should be done in order to meet national agriculture research priorities and immediate local level needs.

8. The CAESC model is the most interesting REE platform that could be built to engage the actors in increasing the efficiency of agricultural research, teaching and learning mechanism while addressing the needs and problems of the producers. To achieve this, it requires enormous changes in how we think about the CAESC.

\section{References}

Adesiji G. B., M. Ibrahim and S. E. Komolafe. (2017). Comparative assessment of agricultural technology generating practices in universities and research institutes in north central zone of Nigeria. Information processing in agriculture 4 (2017): 161-167. Available at www.sciencedirect.com

ADS. (2014). Agriculture Development Strategy (2015-2035). Ministry of Agriculture Development (MoAD). Shingadurbar, Kathmandu.

Agbamu J. U. (2000). Agricultural research-extension linkage systems: an international perspective available at www.odi.org/sites/odi.org.uk/files/odi-assets/publications-opinion-files/8202.pdf

Belay Kassaand D. Alemu. (2017). Agricultural Research and Extension Linkages: Challenges and Intervention OptionsAvailablefrom:https://www.researchgate.net/publication/312563353_Agricultural_Research_and_Exte nsion_Linkages_Challenges_and_Intervention_Options[accessed Oct 13 2018]

Anandajayasekeram P, Puskur R, SinduWorkneh and Hoekstra D. 2008. Concepts and practices in agricultural extension in developing countries: A source book. IFPRI (International Food Policy Research Institute), Washington, DC, USA, and ILRI (International Livestock Research Institute), Nairobi, Kenya.

Belay K. (2008). Linkage of Higher Education with Agricultural Research, Extension and Development in Ethiopia.

International Association of Universities 0952-8733/08 \$30.00 www.palgrave-journals.com/hep available at http://citeseerx.ist.psu.edu/viewdoc/download?doi=10.1.1.694.3878\&rep=rep1\&type=pdf Bull H., L S. Cote, P. D. Warner and M. Ray McKinnie (2004). Is Extension Relevant for the 21st Century? Journal of extension, 42 (6): 60-available at https://www.joe.org/joe/2004december/comm2.php

Crowder, L. van \& Anderson, J. (1997). Linking research, extension and education: why is the problem so persistent and pervasive?, European Journal of Agricultural Education and Extension, 3:4, 241249, DOI: $10.1080 / 13892249785300061$

Deneke, T.T. \&Gultih, D. (2016). Agricultural Research and Extension Linkages in the Amhara Region, Ethiopia. In F.W. Gatzweiler\& Braun, J. von (eds.), Technological and Institutional Innovations for Marginalized Smallholders in Agricultural Development, DOI 10.1007/978-3-319-25718-1_7 Available at ttps://link.springer.com/content/pdf/10.1007\%2F978-3-319-25718-1_7.pdf

Dongol, BBS (2015). Extension education (2nd edition). Kathmandu Nepal, Prativa S. Dongol.

Dorothy, T. F. (1993) Linking Institutional Missions to University and College Archives Programs: The Land Grant Model American Archivist / Vol. 56

Gauchan D. \& Paudel, M.N. (2012). A proposal for restructuring of Nepal Agricultural Research Council (NARC) in the new federal system of the country. Proceedings of the 10th National Outreach Workshop, 27-28 February 2012 RARS, Lumle, Kaski

Hoffmann V., J. Lamers and A. D. Kidd. 2000. Reforming the organisation of agricultural extension in Germany: Lessons for other countries. Agriculture research and extension network. Paper series 98.

IAAS. (2011). IAAS Bulletin. Tribhuvan University, Institute of Agriculture and Animal Science, Rampur, Chitwan, Nepal, $100 \mathrm{p}$ 
Jaishi M., Nepali, P.B. \&Shahi, L. (2018). Agricultural Extension in Nepal under Federalism: Agriculture extension in South Asia (AESA) Working Paper 2018-005

Jaishi M, Shahi, L. and Khatiwada, B. (2013). Decentralized agriculture development in VDC: Experience from Okhaldhunga district. In Participation: A Nepalese Journal of Participatory Development Rai, U. (eds.), 15 (14):100-110 pp.

Jaishi M., Shahi, L. and Khatiwada, B. (2013). Decentralized agriculture development in VDC: Experience from Okhaldhunga district. Participation: A Nepalese Journal of Participatory Development(Rai U. eds.), 15 (14):100-110 pp.

Joshi N.N. (2016). Addressing poverty by reorienting agricultural research, extension and education in Nepal. In Land agriculture and agrarian transformation (Pyakuryal KP and Upreti BR eds.). New Delhi: Adroits Publishers.

Local Governmence Operation Act (2017). Available at: www.law commission.gov.np

Mishara S., L.P. Sahoo, A. Sarkar, G. Maharana, S. Agrade, B.C. Behera, S. Das and K. Shimran, 2018. Gender sensitive extensions strategies for engendering agriculture research and extension. In Souvenir extension strategies and challenges for doubling farm income (Sadangi et al. Eds), IEC February 1-3, 2018, ICARCIWA Bhuwaneshwor, India.

MoAD. (2014). Agriculture development strategy (2015-2035). Ministry of Agriculture Development, Shinha Durbar, Kathmandu.

National Research Council. (1996). Colleges of Agriculture at the Land Grant Universities: Public Service and Public Policy. Washington, DC: The National Academies Press. doi: 10.17226/5133

Nepali P.B. 2018. Possibility and relevance of Land Grant University Model in Nepal in federal context for inclusive agrarian transformation. Spotlight Magazine. Available at: https://www.spotlightnepal.com/2018/01/28/ possibility-and-relevance-land-grant-universitymodel-nepalfederal-context/

Nepali, P. B., Jaishi, M, \&. Baral, P. (2018). Relevancy of Land Grant University and college: Model for inclusive agrarian transformation in federalized Nepal. Conference paper in international conference on doubling farm income of farmers of SAARC countries: extension strategies and approaches, 20-23 September 2018, Kathmandu Nepal

Parajuli, M.N. (2017). NAPA Research/policy brief. Agricultural Education, Research, and Extension in Nepal: Role of Expatriates, Association of Nepalese Agriculture Professional of America

Paudel K.P., Bhattarai, T., and Subedi, Y.P. (2016). Nepal's agriculture development: Civic analysis of Nepal agriculture development Strategy 2015. Alliance for agriculture and food (AAF), Forest Action Nepal.

Paudel S.,.Gill T. \&. Rajotte E. (2013). Agriculture education and training (AET) system in Nepal: present status, challenges and future priorities. INNOVATE/USAID/ The Pennsylvania State University

Paudyal, K.P. (2011). Improvement in Agricultural Research Structure in Federal System: A Concept. Horticultural Research Division, NARC, Khumaltar

R.K. Samanta and B. S Sontakki (2006). Strengthening Research-Extension Linkages for Effective Delivery of Agricultural Technologies: Human Centered Approach. In Proceecdings of the regional Workshop on ResearchExtension Linkages for Effective Delivery of Agricultural Technologies in SAARC Countries, SAIC, Bangaldesh Dhaka

Roling N. 1990. The agricultural research-technology transfer interface. A knowledge systems perspective. In: Kaimowitz D (ed), Making the link. Agricultural research and technology transfer in developing countries. Westview Press, Boulder, Colorado, USA.

Sadighi, H. (2005). Education, and Extension Linkages: An Analysis of Institutions in Developing Countries. AIAEE Proceedings of the 21st Annual Conference San Antonio, TX Research, available at https://www.aiaee.org/attachments/article/986/125.pdf

Schutjer, W.A. (1991). Rural Development and Extension. Journal of Extension, Volume 29:(1) available at https://www.joe.org/joe/1991spring/tp1.php

Singh, K.M., Meena M.S. \& Swanson, B. E. (2013). Role of State Agricultural Universities and Directorates of Extension Education in Agricultural Extension in India Online at https://mpra.ub.uni-muenchen.de/49108/ MPRA Paper No. 49108,

Stoecker, R. (2014). Extension and Higher Education Service Learning: Toward a Community Development ServiceLearning Model. (C) Journal of Higher Education Outreach and Engagement, 18 ( 1): 15: available at htpps//files.eric.ed.gov/fulltext/EJ1024165.pdf 
Subedi M. \& McNamara, P. (2012). Strengthening the pluralistic agricultural extension system in Nepal. MEAS/USAID

Subedi T.B, Subedi, R. \&Sapkota, B.R (2018). Agriculture extension system in Nepal: Context of federal restructuring. Conference paper in international conference on doubling farm income of farmers of SAARC countries: extension strategies and approaches, 20-23 September 2018, Kathmandu Nepal

Taylor M and S. Bhasme, 2018. Model farmers, extension networks and the politics of agricultural knowledge transfer. Journal of Rural Studies(64): 2018, 1-10 available athttps://doi.org/10.1016/j.jrurstud.2018.09.015

Teklewold T. D. and Daniel Gulti (2016). Agricultural Research and Extension Linkages in the Amhara Region, Ethiopia. In Gatzweiler, F. W. and Joachim von Braun (Editors).Technological and institutional Innovations for Marginalized small holders in Agricultural Development. Springer Cham Heidelberg New York Dordrecht London 